\title{
Scleroderma spp. in Indonesia : Poisoning Case and Potential Utilization
}

\author{
Ivan Permana Putra \\ Divisi Mikologi, Departemen Biologi, Institut Pertanian Bogor, Indonesia \\ ivanpermanaputra@apps.ipb.ac.id
}

\section{ARTICLE INFO}

\section{Article History:}

Received : 12-10-2020

Revised : 03-11-2020

Accepted : 09-11-2020

Online : 29-11-2020

\section{Keywords:}

Wild Mushroom;

Food; Scleroderma;

Toxicity; Potency

\begin{abstract}
Abstract : Mushroom are functional food which has been consumed for long time due to the various benefits and are rich in nutrients for health. Even though it is not the main food ingredient, local people in Indonesia are accustomed to consuming wild mushroom in the vicinity. One of these mushroom is Scleroderma spp. which grows as ectomycorrhizal mycobiont usually around the Gnetum gnemon L. plant. This study aimed to provide the information regarding poisioning case of Scleroderma in Indonesia and also it's potential utilization. This paper is a literature-based quantitative research. Several previous studies have confirmed the benefits of this mushroom such as antioxidant, antibacteria, and anti-inflammatory which is beneficial for health. However, the result showed that during the last 10 years, there have been 6 cases of poisoning due to consumption of Scleroderma in Indonesia. A total of 54 people have become victims and 4 of them have died. Scleroderma spp. known to be easily found in various places throughout Indonesia. This mushroom is generally recommended to be consumed only in the young fruiting body phase. Some cases of poisoning. are thought to be due to the sclerocitrin content in the fruiting body of this mushroom.
\end{abstract}

\begin{abstract}
Abstrak : Jamur merupakan salah satu bahan pangan yang telah sejak lama dikonsumsi karena memiliki berbagai manfaat dan kaya akan kandungan bahan bioaktif untuk kesehatan. Walaupun belum menjadi bahan pangan utama, masyarakat lokal di Indonesia telah terbiasa untuk mengkonsumsi jamur liar yang ada di sekitarnya. Salah satu dari jamur tersebut adalah Scleroderma spp. yang tumbuh sebagai mikobion pembentuk ektomikoriza umumnya di sekitaran tanaman melinjo (Gnetum gnemon L.). Penelitian ini bertujuan untuk menyediakan informasi mengenai kasus keracunan Scleroderma di Indonesia serta potensi pemanfaatannya. Tulisan ini merupakan penelitian kuantitatif berbasis literatur. Meskipun beberapa penelitian sebelumnya telah mengkonfirmasi manfaat dari jamur ini seperti: antioksidan, antibakteri, dan antiinflamasi yang bermanfaat untuk kesehatan. Selama 10 tahun terakhir, telah terjadi 6 kasus keracunan akibat pengkonsumsian jamur liar Scleroderma di Indonesia. Sebanyak 54 orang telah menjadi korban dan 4 diantaranya meninggal dunia. Scleroderma spp. diketahui mudah ditemukan di berbagai tempat di seluruh Indonesia. Jamur ini umumnya disarankan hanya dikonsumsi pada fase tubuh buah yang masih muda. Beberapa kasus keracunan diduga juga karena kandungan sclerocitrin yang terdapat pada tubuh buah dari jamur ini.
\end{abstract}




\section{A. LATAR BELAKANG}

Jamur merupakan organisme heterotrof yang bisa ditemukan di berbagai relung ekologi karena gaya hidupnya yang kosmopolitan (Putra et al., 2017)(Putra, Sitompul, and Chalisya 2018)(Putra et al., 2018)(Putra, Nasrullah, and Dinindaputri 2019)(Putra, Amelya, Veronica, et al. 2020)(Putra et al., 2020)(Putra, 2020a)(Putra, Amelya, Nugraha, et al. 2020)(Putra, 2020c)(Putra 2020). Hingga saat ini telah diketahui sebanyak $70.000-140.000$ jamur yang telah didokumentasikan (Hawksworth 2001)(Blackwell 2011) dari total estimasi 1.500 .000 jamur yang berada di alam (Blackwell 2011). Dari jumlah jamur yang telah diketahui tersebut, diperkirakan sebanyak 2000 jenis merupakan jamur yang aman untuk dikonsumsi dan 700 diantaranya juga digunakan sebagai agen terapi medis (Lima et al., 2012), sehingga dianjurkan untuk dikonsumsi. Jamur telah menjadi salah satu sumber bahan pangan fungsional oleh manusia, dan termasuk jamur-jamur liar (non budidaya). Jamur dianggap sebagai sumber makanan rendah kalori dan kaya akan protein nabati, mineral, dan vitamin (Chang dan Miles 2004)(Wang et al. 2014). Selain itu, jamur juga telah digunakan dalam bidang kesehatan (Wu et al., 2016; Money 2016)(Hsieh and Ju 2018) karena banyak mengandung bahan bioaktif yang berfungsi sebagai antikanker, antibakteri, antifungi, antivirus, antioksidan, antiinflamasi dan produk turunan lainnya (Adhikari 2020).

Namun, karena secara morfologi memiliki tubuh buah yang terkadang sangat mirip satu dengan lainnya, maka kasus-kasus keracunan jamur liar bisa terjadi akibat kesalahan identifikasi (Lima et al., 2012) , pengkonsumsian tubuh buah jamur di fase yang salah, ataupun kuantitas racun dengan kadar tertentu sebagai akibat banyaknya jumlah tubuh buah jamur yang dikonsumsi (Sato et al. 2020). Beberapa kelompok jamur seperti Coprinus diketahui memiliki perubahan kandungan pada tubuh buahnya ketika menua ataupun akibat terpapar alkohol sehingga menjadi beracun untuk dikonsumsi oleh manusia (Peredy, 2014). Jamur-jamur lainnya seperti Macrocybe diketahui memiliki kandungan sianida ataupun bentuk racun lainnya namun pada kadar yang beragam (Pegler, 1998; Sato et al., 2020). Salah satu jamur liar yang telah lama dikonsumsi oleh banyak masyarakat lokal di Indonesia adalah Scleroderma spp. (Putra dan Khafazallah, 2020) atau yang juga dikenal sebagai jamur tangkil/ so (Jawa), Jamur kodok (Betawi), dan jamur melinjo (umum), walaupun beberapa laporan lainnya juga menyebutkan bahwa masyarakat menganggap jamur ini sebagai jamur beracun (Susan and Retnowati 2018)(Annissa et al. 2017). Jamur ini mudah ditemukan di berbagai wilayah di Indonesia di sekitaran pohon terutama melinjo (Gnetum gnemon L.) .

Hingga saat ini, selama sepuluh tahun terakhir (2010-2020) telah terjadi sejumlah 76 kasus keracunan berbagai jamur liar di Indonesia dengan 550 korban dan 9 diantaranya meninggal dunia (Putra, 2020 tidak dipublikasikan) dimana beberapa diantaranya diakibatkan oleh Scleroderma spp. Scleroderma yang dikonsumsi oleh korban diduga pada fase tua tubuh buah dari jamur ini ataupun mengkonsumsi dalam jumlah yang banyak. Pengetahuan yang baik merupakan salah satu kunci untuk mencegah terjadi kasus keracunan jamur. Tulisan ini bertujuan untuk memberikan informasi terkait kasus keracunan Scleroderma di Indonesia, karakteristik identifikasi dari Scleroderma spp., distribusi, karakter identifikasi, pemanfaatan, dan potensi toksisitasnya. 


\section{B. METODE PENELITIAN}

Informasi yang digunakaan dalam penulisan ulasan ini diperoleh melalui hasil penelitian sendiri dan juga studi pustaka. Penelusuran pustaka online dilakukan melalui laman akademik yang menyediakan jurnal ilmiah gratis dan berbayar seperti sciencedirect, researchgate, googlescholar, wiley online library dan lain-lain. Informasi dikumpulkan dengan menggunakan kata kunci yang berhubungan dengan penulisan ulasan ini misalnya Scleroderma distribution, Scleroderma nutrition, Scleroderma poisoning. Sementara itu, karena tidak adanya pangkalan data yang baik untuk kasus keracunan jamur di Indonesia, informasi mengenai keracunan jamur tangkil/so/ melinjo di Indonesia dilakukan melalui laman surat kabar cetak dan elektronik selama 10 tahun terakhir. Selanjutnya informasi yang diperoleh kemudian diolah, dianalisis, dan dibuatkan data dalam bentuk tabel dan grafik, disintesis, serta disusun untuk menjelaskan pandangan penulis terkait terkait distribusi, aspek identifikasi, potensi pemanfaatan, dan resiko toksisitas Scleroderma spp.

\section{HASIL DAN PEMBAHASAN}

\section{Keracunan Scleroderma di Indonesia}

Hasil inventarisasi informasi mengkonfirmasi bahwa telah terjadi sebanyak 6 kasus (Tabel 1) keracunan karena mengkonsumsi Scleroderma spp. selama periode 10 tahun (2010-2020) di Indonesia. Sejumlah 54 orang diketahui telah menjadi korban dengan 4 diantaranya meninggal dunia (Gambar 1). Semua tubuh buah jamur yang dikonsumsi tumbuh di sekitaran pohon melinjo. Informasi mengenai kasuskasus keracunan yang ditemukan hanya berasal dari 4 propinsi yakni Jawa Tengah, Aceh, Sumatera Selatan, dan Jawa Barat. Hal ini sejalan dengan beberapa laporan penelitian yang menyebutkan bahwa jamur ini banyak dilaporkan dari Pulau Jawa dan masyarakatnya sering mengkonsumsi jamur tersebut (Hayati 2013)(Rifai, 2017; Putra dan Khafazallah, 2020).

Tabel 1. Kasus Keracunan Scleroderma spp. di Indonesia Periode 2010-2020

\begin{tabular}{|c|c|c|c|c|c|}
\hline No & Tahun & $\begin{array}{l}\text { Jumlah } \\
\text { Korban }\end{array}$ & Lokasi & Informasi Ciri Jamur & Tempat Hidup \\
\hline 1 & 2010 & 4 & $\begin{array}{l}\text { Banjarnegara } \\
\text { (Jawa Tengah) }\end{array}$ & $\begin{array}{l}\text { Jamur berbentuk bulat } \\
\text { (dikenal oleh korban } \\
\text { sebagai jamur so) }\end{array}$ & $\begin{array}{l}\text { Tanah } \\
\text { bercampur } \\
\text { jerami dekat } \\
\text { pohon melinjo }\end{array}$ \\
\hline 2 & 2011 & 6 & Sigli (Aceh) & $\begin{array}{l}\text { Korban sudah terbiasa } \\
\text { mengkonsumsi jamur } \\
\text { melinjo tersebut }\end{array}$ & $\begin{array}{l}\text { Di bawah pohon } \\
\text { melinjo }\end{array}$ \\
\hline 3 & 2013 & 29 & $\begin{array}{l}\text { Empat Lawang } \\
\text { (Sumatera } \\
\text { Selatan) }\end{array}$ & $\begin{array}{l}\text { Jamur berbentuk bulat dan } \\
\text { diperjual belikan }\end{array}$ & $\begin{array}{l}\text { Tumbuh di } \\
\text { sekitaran pohon } \\
\text { melinjo }\end{array}$ \\
\hline 4 & 2015 & 5 & $\begin{array}{l}\text { Pekalongan (Jawa } \\
\text { Tengah) }\end{array}$ & Jamur so & $\begin{array}{l}\text { Di bawah pohon } \\
\text { melinjo }\end{array}$ \\
\hline 5 & 2017 & 4 & $\begin{array}{l}\text { Banjarnegara } \\
\text { (Jawa Tengah) }\end{array}$ & Jamur so & $\begin{array}{l}\text { Di bawah pohon } \\
\text { melinjo }\end{array}$ \\
\hline 6 & 2018 & 6 & $\begin{array}{l}\text { Purwakarta (Jawa } \\
\text { Barat) }\end{array}$ & $\begin{array}{l}\text { Jamur tumbuh di bawah } \\
\text { pohon melinjo }\end{array}$ & $\begin{array}{l}\text { Sekitaran pohon } \\
\text { melinjo }\end{array}$ \\
\hline
\end{tabular}




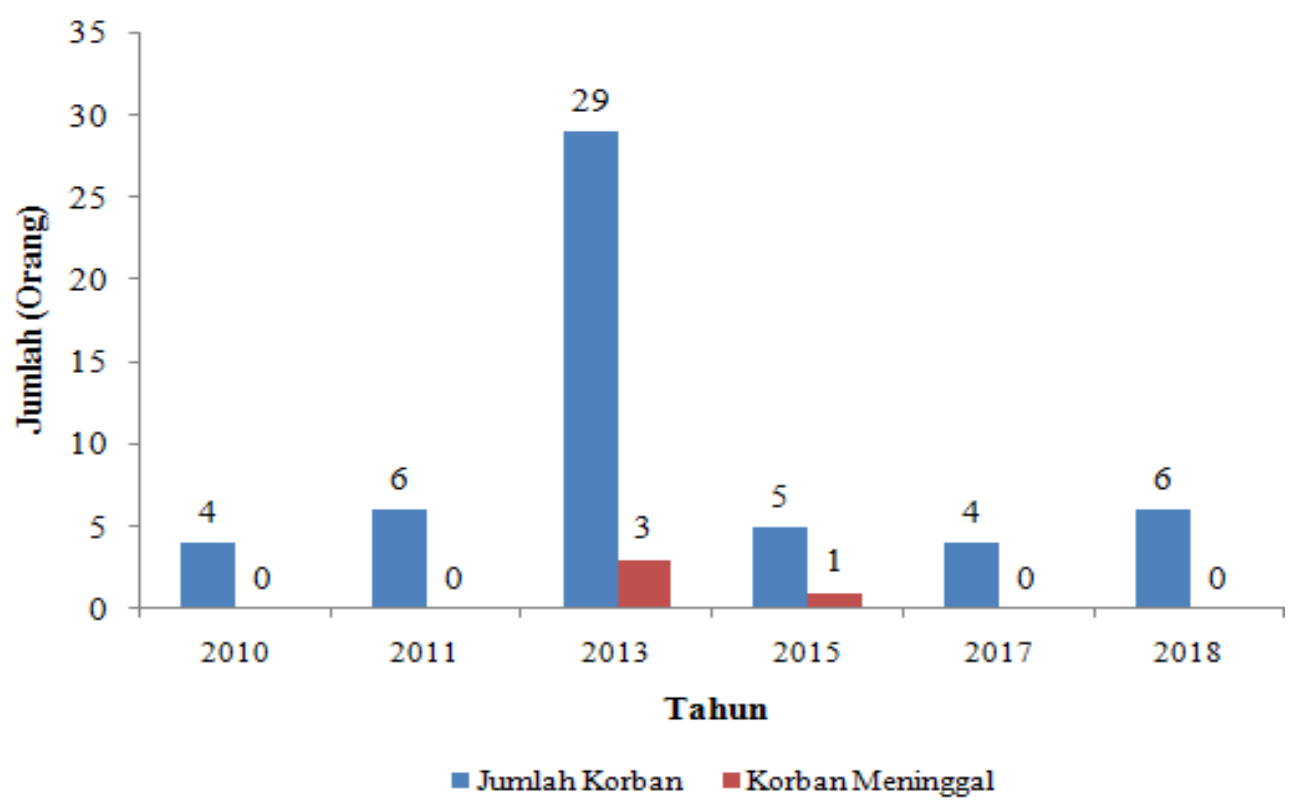

Gambar 1. Jumlah Korban Keracunan Scleroderma spp. di Berbagai Wilayah di Indonesia Pada 2010-2020

Setengah dari kasus keracunan jamur tersebut terjadi di Jawa Tengah dengan jumlah korban sebayak 13 orang. Namun jumlah korban keracunan paling banyak terjadi di Sumatera Selatan yakni sebanyak 29 orang pada tahun 2013. Korban meninggal dunia terjadi hanya pada tahun 2013 dan 2015. Publikasi mengenai kasus keracunan jamur di Indonesia hanya pernah dilaporkan oleh Putra (2020), yakni dari genus Inocybe.

\section{Distribusi Scleroderma spp.}

Scleroderma spp. bersifat kosmopolitan dan tersebat mulai dari daerah empat musim hingga tropis dan membentuk ektomikoriza dengan berbagai jenis tanaman kehutanan terutama melinjo (Gnetum gnemon L.) (Kumla et al., 2013). Berdasarkan data dari indexfungorum (http://www.indexfungorum.org/Names/Names.asp; diakses pada 23 agustus 2020) terdapat sebanyak 186 speises, subspesies, dan varietes Scleroderma dari seluruh dunia. Di Indonesia sendiri jamur ini telah dilaporkan dari berbagai tempat seperti Jawa Timur (Hayati 2013) yakni Scleroderma spp., Bengkulu (Susan dan Retnowati, 2017) yakni S. sinnamariense Mont, Kalimantan Barat (Annisa et al., 2017) yakni S. citrinum, Pulau Jawa (Rifai, 2017) yakni catatan mengenai $S$. pseudostipitatum dan S. nitidum, Kalimantan Tengah dan Jawa Barat (Putra dan Khafazallah, 2020) yakni S. cf. sinnamariense Mont. dan S. cf. citrinum.

Walaupun belum terdapat checklist yang lengkap dan terkini untuk Scleroderma dan jamur lainnya di Indonesia, namun pemanfaatan jamur ini sebagai bahan pangan oleh masyarakat telah cukup lama dilakukan (Putra dan Khafazallah, 2020). Hal ini dikarenakan persebaran dari jamur ini yang luas sehingga peluang interaksinya dengan manusia menjadi sangat tinggi. Umumnya, kasus keracunan jamur liar terjadi karena korban salah mengenali (identifikasi) jamur yang terlihat mirip satu dengan lainnya. Scleroderma spp. memiliki kemiripan dengan kelompok puffball lainnya seperti Calvatia, Lycoperdon, Rhizopogon, ataupun Bovista (Arora, 1986). Walaupun tidak semua kelompok puffball beracun, namun pengetahuan dasar mengenai 
karakter utama untuk mengenali jamur yang bisa dikonsumsi merupakan salah satu cara untuk menghindari terjadinya keracunan.

\section{Karakter Identifikasi Scleroderma spp.}

Posisi taksonomi Scleroderma spp. (mengikuti acuan dari indexfungorum) : Sclerodermataceae, Boletales, Agaricomycetidae, Agaricomycetes, Agaricomycotina, Basidiomycota, Fungi. Scleroderma, terutama yang umumnya ditemukan di Indonesia memiliki ciri sebagai berikut : tubuh buah jamur ini berbentuk bulat hingga lonjong sehingga disebut sebagai puffball. Permukaan peridium luar keras, halus dengan retakan kecil, hingga kasar dengan retakan besar (Arora, 1986; Desjardin et al., 2015). Warna tubuh buah bervariasi mulai dari kuning (Gambar 1.a;c) hingga kecoklatan (Gambar 1.b). Himenofor jamur ini berbentuk gleba (Gambar 1e;c;f) yang dilapisi dengan peridium dalam (Gambar 1d) yang hanya terlihat jika tubuh buah pecah atau dibelah sebagai penciri dari perkembangan basidioma angiokarpus (selalu tertutup) (Rokuya et al., 2011).

Pada fase muda bagian dalam tubuh buah berwarna putih hingga krem (Gambar 1e;c) dan berubah menjadi hitam (hanya bagian gleba) ketika telah dewasa (Gambar 1f). Bagian hitam tersebut merupakan massa dari spora yang akan dikeluarkan ketika terdapat tekanan ataupun kondisi lingkungan yang memecahkan tubuh buah jamur ini. Tubuh buah umumnya tumbuh sesil di atas permukaan tanah ataupun dilengkapi dengan tangkai semu (pseudostipe). Warna tangkai umumnya sama dengan warna permukaan pileus ataupun sedikit memudar. Bagian basal dari tubuh buah atau tangkai semu jika digali akan terhubung ke rizomorf (modifikasi hifa yang menghubungkan tubuh buah jamur dengan akar dari tumbuhan inangnya.

\section{Manfaat dan Potensi Scleroderma spp.}

Beberapa penelitian sebelumnya telah menunjukkan potensi pemanfaatan Scleroderma dalam bidang pangan. Jamur ini telah dimanfaatkan sebagai bahan pangan oleh masyarakat lokal di Jawa Timur (Hayati, 2013) yakni Scleroderma spp. (dikonsumsi), dijual di berbagai pasar tradisional Indonesia (Boa, 2014) yakni $S$. sinnamariense Mont. (sebagian masyarakat mengkonsumsinya dan sebagian lagi mengganggapnya sebagai jamur beracun), Kalimantan Barat (Annisa et al., 2017) yakni S. citrinum (sebagian masyarakat mengkonsumsinya dan sebagian lagi mengganggapnya sebagai jamur beracun), Pulau Jawa (Rifai, 2017) yakni catatan mengenai $S$. pseudostipitatum dan S. nitidum (namun tidak diketahui dengan jelas pemanfatannya), Kalimantan Tengah dan Jawa Barat (Putra dan Khafazallah, 2020) yakni $S$. cf. sinnamariense Mont. (dikonsumsi) dan $S$. cf. citrinum (tidak diketahui). Umumnya, sebagian besar masyarakat mengkonsumsinya pada fase mudah jamur ini.

Selain dimanfaatkan dalam bidang pangan, jamur ini juga telah dilaporkan sebagai bahan biokatif untuk medis dan kesehatan. Beberapa penelitian menunjukkan bahwa polisakarida dari $S$. citrinum memiliki aktivitas antiinflamasi dan efektif unuk menanggulangi edema dengan cara meregulasi cytokine (Nascimento et al., 2011)(da Silva Nascimento Santos and Leite 2015) 


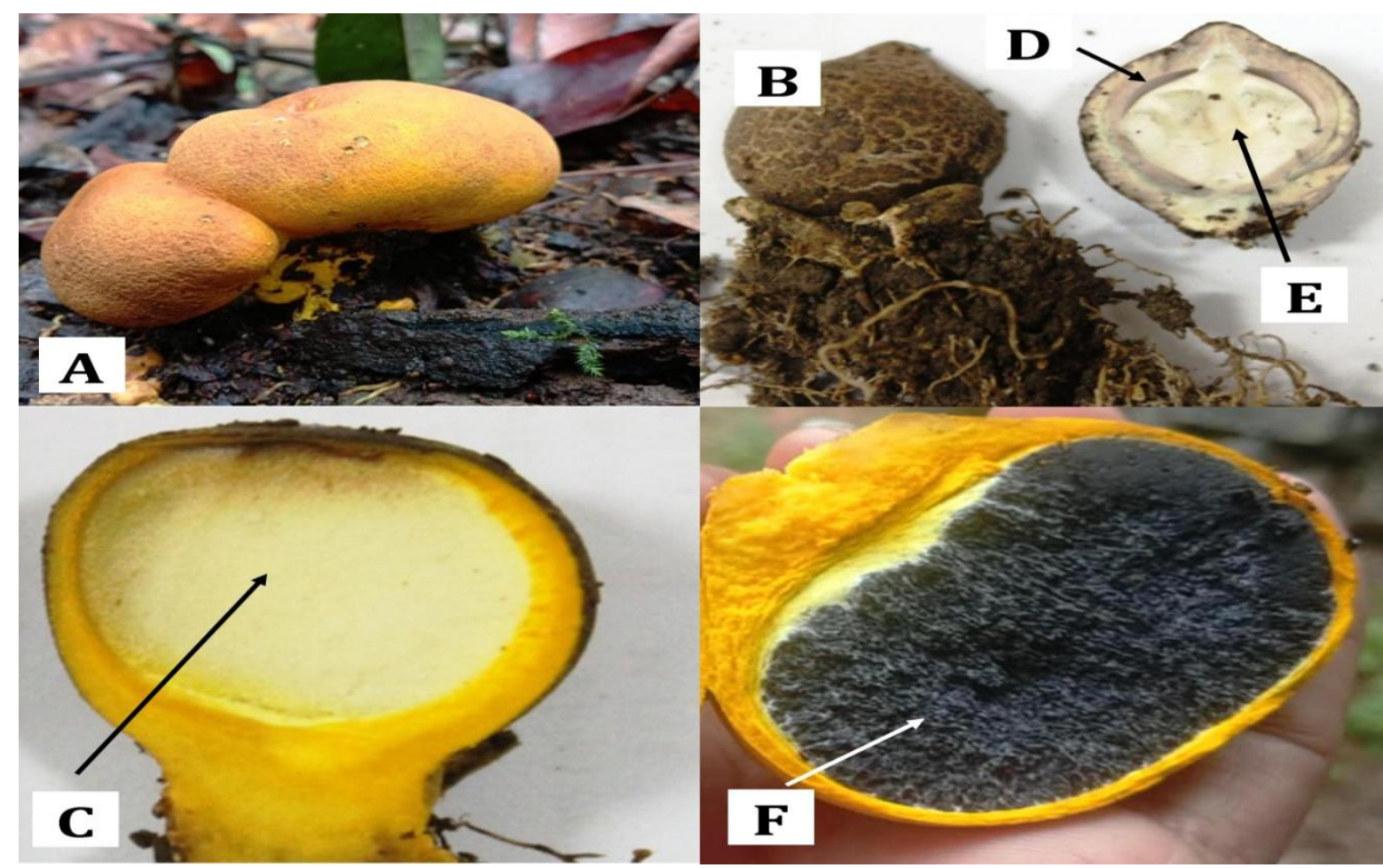

Karakter Identifikasi Makroskopis Scleroderma cf. sinnamariense (A) dan $S$. citrinum (B). (Dokumentasi penulis).

Sementara itu Lopusiewicz (2018) mengkonfirmasi bahwa ekstrakmelanin dari $S$. citrinum yang telah dipurifikasi memiliki aktivitas antioksidan dan antibakteri. Namun, hingga saat ini belum ditemukan adanya laporan mengenai analisis nutrisi dan potensi bahan bioaktif jamur ini di Indonesia.

\section{Aspek Toksisitas Scleroderma spp.}

Hingga saat ini perdebatan mengenai edibilitas berbagai jenis Scleroderma spp. masih terjadi. Sebagai contoh, beberapa peneliti melaporkan bahwa beberapa masyarakat mengkonsumsi $S$. sinnamariense, namun sebagian lagi menganggapnya beracun (Zhang et al., 2013)(Hayati 2013)(Karun and Sridhar 2017). Susan dan Retnowati, 2017). Bahkan Læssøe et al., (2019) melaporkan bahwa S. sinnamariense dikategorikan sebagai jamur beracun di Laos, namun Boa et al., (2014) dalam laporannya menyebutkan bahwa jenis-jenis dari kelompok jamur ini merupakan jamur liar edible yang banyak digunakan oleh masyarakat lokal di seluruh dunia, termasuk Indonesia.

Informasi dan pengetahuan mengenai senyawa toksik dan penanganan keracunan kelompok jamur Scleroderma masih sangat minim (Sato et al., 2020). Namun gejala keracunan jamur ini cukup diketahui dengan baik. Secara umum gejala tersebut meliputi muntah, diare, dan gangguan pencernaan. Hasil pengumpulan informasi keracunan Scleroderma di Indonesia menunjukkan bahwa dari kasus yang terjadi seluruh korban mengalami gejala pusing, mual, muntah, diare ataupun kombinasinya hingga ada yang menyebabkan kematian.

Jenis toksin yang dilaporkan berasal dari Scleroderma adalah sclerocitrin (Sato et al., 2020). Racun ini juga diketahui menyebabkan gangguan pada sistem syaraf dan memiliki efek seperti muscarine, walaupun aktivitas biologinya belum dapat dijelaskan. Jenis racun ini diidentifikasi dari S. albidum yang menyebabkan keracunan pada kakek berumur 66 tahun di Jepang yang memakan jamur ini dalam jumlah yang 
lebih banyak dari istrinya (istrinya tidak mengalami keracunan). Sehingga dapat diasumsikan bahwa kuantitas dari racun yang masuk ke dalam tubuh juga merupakan salah faktor penyebab keracunan. Selain itu, korban salah menduga jamur yang diambilnya sebagai Rhizopogon roseolus yang merupakan jamur edible. Racun ini dapat diidentifkasi karena adanya koordinasi yang baik antara peneliti dan pemerintah. Di Indonesia sendiri, kendala utama identifikasi jamur penyebab keracunan salah satunya adalah minimnya informasi, preservasi, ataupun dokumentasi yang baik mengenai sampel jamur beracun. Hingga saat ini, belum ditemukan adanya publikasi mengenai kandungan racun dari Scleroderma di Indonesia.

\section{SIMPULAN}

Scleroderma spp. merupakan jamur liar yang telah banyak dikonsumsi baik di Indonesia ataupun di berbagai negara lainnya.Walaupun juga telah dilaporkan memiliki berbagai kandungan bahan bioaktif yang baik untuk kesehatan, namun kasus keracunan jamur ini masih terjadi. Spesies yang diambil dan jumlah biomassa yang dimakan merupakan variabel penting namun menjadi hal yang belum bisa dijelaskan secara detil terkait keracunan Scleroderma.

\section{E. SARAN}

Diperlukan pengetahuan, pengalaman, dan kehati-hatian dalam mengkonsumsi Scleroderma yang tumbuh liar guna mencegah terjadinya keracunan.

\section{UCAPAN TERIMA KASIH}

Penulis mengucapkan terimakasih kepada Komunitas Pemburu Jamur Indonesia yang telah membantu penulisan ini.

\section{REFERENSI}

Arora, D. (1986). Mushrooms Demystified. USA: Teen Speed Press.

Adhikari, Mahesh Kumar. 2020. "Some Antiviral Mushrooms of Nepal." Nepal Journal of Science and Technology 19(1): 54-59.

Annissa, Iin, Ekamawanti, Hanna Artuti, and Wahdina. 2017. "Keanekaragaman Jenis Jamur Makrokopis Di Arboretum Sylva Universitas Tanjungpura." Jurnal Hutan Lestari 5(4): 969-77.

Blackwell, Meredith. 2011. “The Fungi: 1, 2, 3 ... 5.1 Million Species?” American Journal of Botany 98(3): 426-38.

Boa, E. (2004). Wild Edible Fungi: A GlobalOverview of Their Use and Importance to People. Rome : FAO.

Chang ST, Miles P. (2004). Cultivation techniques.in Chang ST, Miles P, Mushroom, Cultivation, Nutritional Value and Medicinal Effect and Environmental Impact. NewYork (US): CRS Press.

Desjardin, D. E., Wood, M., \& Stevens, F. A. (2015). California mushrooms: The comprehensive identification guide. Portland: Oregon.

Hawksworth, David L. 2001. "The Magnitude of Fungal Diversity: The 1.5 Million Species Estimate Revisited." In Mycological Research, , 1422-32.

Hayati, Nur. 2013. "Karakterisasi Morfologi Dan Anatomi Jamur Ektomikorhiza Scleroderma Spp. Pada Tanaman Melinjo (Gnetum Gnemon L.) Di Kabupaten Pacitan." Jurnal Bioma 2(1): 32-48. 
Hsieh, Huei Mei, and Yu Ming Ju. 2018. "Medicinal Components in Termitomyces Mushrooms." Applied Microbiology and Biotechnology 102(12): 4987-94.

https://regional.kompas.com/read/2017/07/12/15565851/diduga.keracunan.jamu r.satu.keluarga.dilarikan.ke.rumah.sakit?page=all [diakses pada 05-08-2020].

https://www.tribunnews.com/regional/2011/03/31/satu-keluarga-keracunanjamur [diakses pada 05-08-2020].

https://www.jpnn.com/news/puluhan-keracunan-jamur-tiga-tewas [diakses pada 05-08-2020].

https://jateng.tribunnews.com/2015/03/27/sekeluarga-di-pekalongan-keracunanjamur-satu-orang-tewas [diakses pada 05-08-2020].

https://sains.kompas.com/read/2017/07/12/15565851/diduga.keracunan.jamur.sa tu.keluarga.dilarikan.ke.rumah.sakit?page=all [diakses pada 05-08-2020].

https://jabar.tribunnews.com/2018/02/27/warga-keracunan-jamur-hal-biasa-yangterjadi-di-purwakarta [diakses pada 05-08-2020].

Karun, Namera C., and Kandikere R. Sridhar. 2017. "Edible Wild Mushrooms of the Western Ghats: Data on the Ethnic Knowledge." Data in Brief 14: 320-28.

Kumla, J., Suwannarach, N., Bussaban, B., \& Lumyong, S. (2013). Scleroderma suthepense, a new ectomycorrhizal fungus from Thailand. Mycotaxon, 123(1), 17. http://dx.doi.org/10.5248/123.1.

Læssøe, T., Ole, P., Sysouphanthong, P. (2019). Introduction to the Edible, Poisonous and Medicinal Fungi of Northern Laos. Laos : Agro-Biodiversity Project

Lima, A.D., Costa-Fortes R., Carvalho-Garbi N.M.R, Percário, S. (2012) Poisonous mushrooms: a review of the most common intoxications. Nutricion Hospitalaria. 27(2):402-408. DOI: 10.1590/s0212 16112012000200009.

Lopusiewicz, L. (2018). Scleroderma citrinum melanin: isolation, purification, spectroscopic studies with characterization of antioxidant, antibacterial and light barrier properties. World Scientific News. 94(2), 115-130.

Money, N.P., (2016). Are mushrooms medicinal? Fungal Biology, 120(4), pp.449-453. http://dx.doi.org/10.1016/i.funbio.2016.01.006.

Nascimento, M. S., Magalhães, J. E. M., Pinheiro, T. S., Silva, T. A. da, Coutinho, L. G., Baseia, I. G., ... Leite, E. L. (2012). Polysaccharides from the fungus Scleroderma nitidum with anti-inflammatory potential modulate cytokine levels and the expression of Nuclear Factor kB. Revista Brasileira de Farmacognosia, 22(1), 6068.

Putra, Ivan Permana. 2020. "Komunikasi Singkat: Laporan Keberadaan Jamur Beracun Podostroma Cf. Cornu-Damae DARI LUAR BOGOR DI INDONESIA." Konservasi Hayati 16(2): 65-70.

Putra, Ivan Permana, Mega Putri Amelya, Naufal Hafizh Nugraha, and Habibah Zam Zamia. 2020. "Catatan Beberapa Jamur Makro Di Hutan Kampus Institut Pertanian Bogor." Biota 12(2).

Putra, Ivan Permana, Mega Putri Amelya, Septina Veronica, and Muhammad Sholeh Kurnianto. 2020. "Fantastic Fungi Around US: A Case Study Of IPB University Campus Forest." Jurnal Pena Sains 7(2): 68-82.

Putra, Ivan Permana, Muhammad Aldi Nasrullah, and Tiara Aulia Dinindaputri. 2019. "Study on Diversity and Potency of Some Macro Mushroom at Gunung Gede Pangrango National Park." Buletin Plasma Nutfah 25(2): 1.

Putra, Ivan Permana, Rahmadi Sitompul, and Nadiah Chalisya. 2018. "RAGAM DAN Potensi Jamur Makro Asal Taman Wisata Mekarsari Jawa Barat.” Al-Kauniyah: Jurnal Biologi 11(2): 133-50. 
Putra, I.P., Amelya, M.P., Nugara, N.H., Zamia, H.Z. (2019b). Notes of Some Macroscopic Fungi at IPB University Campus Forest: Diversity and Potency. Biota, 12(2), 57-71. https://doi.org/10.20414/jb.v12i2.192.

Putra, I.P., Amelya, M.P., Veronica, S., Kurnianto, M.S. (2020). Fantastic Fungi Around Us: A Case Study Of IPB University Campus Forest. Jurnal Pena Sains, 7(2), 68-82. DOI: https://doi.org/10.21107/jps.v7i2.6753.

Putra, I.P. (2020a). Record On Macroscopic Fungi At IPB University Campus Forest : Description And Potential Utilization. IJOSE, 4(1):1-11.

Putra, I.P. (2020c). Kasus keracunan Inocybe sp. di Indonesia. Prosiding Seminar Biologi di Era COVID-19. Jurusan Biologi, Fakultas Sains dan Teknologi, Universitas Islam Negeri (UIN) Alauddin Makassar. 148-153. DOI: https://doi.org/10.24252/psb.v6i1.15727.

Putra, I.P. \& Hafazallah, K. (2020). Catatan Komunitas Pemburu Jamur Indonesia : Kolaborasi Lintas Profesi dan Generasi Mengenai Etnomikologi Jamur-Jamur Indonesia. Sukabumi : Haura Publishing.

Pegler, D. N., Lodge, D. J., \& Nakasone, K. K. (1998). The Pantropical Genus Macrocybe Gen. nov. Mycologia, 90(3), 494-504. http://dx.doi.org/10.2307/3761408.

Peredy, T.R. (2014). Mushrooms, Coprine. Encyclopedia of Toxicology, 407-408. http://dx.doi.org/10.1016/b978-0-12-386454-3.00754-5.

Rifai, M.A. (2017). Catatan Tentang Scleroderma pseudostipitatum Petch, Scleroderma verrucosum (Bull.) Pers., and Scleroderma nitidum Berk. (Gasteromycetes). Jurnal Mikologi Indonesia, 1(1), 11-14. http://dx.doi.org/10.46638/jmi.v1i1.9.

Rokuya, I., Yoshio, O., Tsugia, H. (2011). Fungi of Japan. Japan: Yama-Kei Publishers.

Sato, Yukio, Hisakuni Tomonari, Yasushi Kaneko, and Kikuo Yo. 2020. " Mushroom Poisoning with Scleroderma Albidum: A Case Report with Review of the Literature ." Acute Medicine \& Surgery 7(1).

da Silva Nascimento Santos, Marilia, and Edda Lisboa Leite. 2015. "Polysaccharides from the Fungus Scleroderma." In Polysaccharides: Bioactivity and Biotechnology, , 2215-32.

Susan, Dewi, and Atik Retnowati. 2018. "Catatan Beberapa Jamur Makro Dari Pulau Enggano: Diversitas Dan Potensinya." BERITA BIOLOGI 16(3).

Wang, Xue Mei et al. 2014. "A Mini-Review of Chemical Composition and Nutritional Value of Edible Wild-Grown Mushroom from China." Food Chemistry 151: 279-85.

Wu, H., Tang, S., Huang, Z., Zhou, Q., Zhang, P., \& Chen, Z. (2016). . International Journal of Medicinal Mushrooms, 18(9), 841-850. http://dx.doi.org/10.1615/intjmedmushrooms.v18.i9.80.

Zhang, C., Xu, X.-E., Liu, J., He, M., Wang, W., Wang, Y., \& Ji, K. (2013). Scleroderma yunnanense, a new species from South China. Mycotaxon, 125(1), 193-200. http://dx.doi.org/10.5248/125.193. 